Open Access

\title{
Does the number of children matter to the happiness of their parents?
}

\author{
Zhilei Shi
}

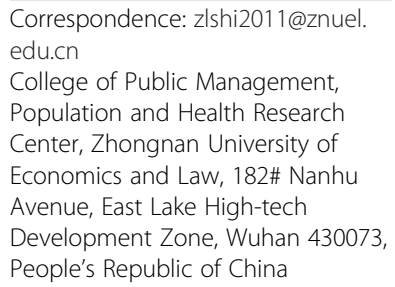

Correspondence: zlshi2011@znuel. edu.cn

College of Public Management, Population and Health Research Center, Zhongnan University of Economics and Law, 182\# Nanhu Avenue, East Lake High-tech Development Zone, Wuhan 430073, People's Republic of China

\begin{abstract}
As the population in China ages, providing care for the elderly in rural China has become an unprecedented challenge. This paper studies how fertility decisions affect the rural elderly, with a specific focus on outcomes for parents with children who are male compared to those whose children are female. This study demonstrates that the educational level of grown children has a positive effect on improving elderly parents' quality of life. Furthermore, preferential treatment of more talented children is more effective than simply increasing the number of children, which in fact has negative influence on the life quality of the parents. Overall, an improvement in the education level of female children does more to improve parents' quality of life than that of male children. However, the scale of effect differs at different stages. In early and middle stages of old age, the health and economic conditions of elderly parents improve as the length of the daughter's education increases. Daughters tend to provide more care to parents than sons. Yet, for later stages, the educational level of sons plays a more significant role in the life quality of the rural elderly.

Keywords: Fertility decision, Years of education, Provision of elderly care, Life quality
\end{abstract}

\section{Background}

For scholars and the government, the focus of care provision for the elderly was on the social security system for older people (Yuan 2001; Liu 2003). The aging population has become a global phenomenon-while western countries are faced with high costs for pensions, China's social security system does not cover both urban and rural populations (Hua 2009) - family care of the elderly has again become the focal point for both the East and the West. China is deeply influenced by Confucian culture, and people have always believed that they should "bring up children for the purpose of being looked after in old age." Further, they believe "the more children, the greater prosperity." Thus, parents rely on their children for care in old age, and children must care for their parents according to both law and morality. The modernization theory of family predicts that, as modernization expands through industrialization, extended kinship ties weaken, traditional family patterns dissolve, the nuclear family becomes a more independent kinship unit, and all these changes will reduce the security provided by family (Goode 1963). In China, family care is further challenged by birth planning policies. The initial purpose of birth planning policies was to control the Chinese population, but the strict implementation of these policies since the late 1970s not only

(C) 2016 The Author(s). Open Access This article is distributed under the terms of the Creative Commons Attribution 4.0 International License (http://creativecommons.org/licenses/by/4.0/), which permits unrestricted use, distribution, and reproduction in any medium provided you give appropriate credit to the original author(s) and the source, provide a link to the Creative Commons license, and indicate if changes were made. 
changed people's fertility behaviors but also influenced families' endowment accumulation and structural function (Shi 2014). There are negative effects of birth planning too; for example, care provisions are difficult for families who have lost their only child, a gender imbalance exists within China as a whole, and elderly care for one-child families can be difficult. All these effects are directly or indirectly related to the decreasing participation of family in providing care for the elderly.

Related western research mainly focuses on the trade-off between the quantity and quality of children (Becker 1960; Hanushek 1992; Martina 1996; Millimet and Wang 2011), the number of children and their parents' labor supply (Angrist and Evans 1998; Lundberg and Rose 2002), and so on. Chinese literature attends to the influence of the number of children on the life quality of the elderly (Xia and Ma 1995; Guo and Zhang 1996; Chen and Du 2002; Geng 2013) but ignores the internal relationship between the quantity/quality of children and the life quality of the elderly. This paper contributes in three ways: firstly, starting from the fertility decision-making model of family, it adds the number of children and the investment in children's education and proposes three fertility strategies aimed at providing family care for the elderly: giving birth to more children, emphasizing children's education, and optimal raising of children; secondly, it estimates the impacts of different fertility strategies on the life quality of the elderly and investigates how to distribute family resources among different children in order to provide better life quality for elderly parents when resources are limited; thirdly, this paper categorizes the ages of parents into three stages and explores how fertility decisions affect the life quality of parents of different age groups. In the next section of this paper, the author will first build a theoretical model. The following section will analyze parents' decisions on the number of children, the gender of children, and their investments in their children, as well as the relationship between these decisions and the quality of life of elderly parents. Then, in the third section, the author will use data from Hubei province to test the hypotheses in the second section. The final section concludes.

\section{Limited resources, fertility decision-making, and family support for the eld- erly in rural China}

Family fertility decisions, number of children, and care provision for the elderly

Since agricultural society has a closed economy, being cared for in one's old age is critical. The more children, the more care one can expect to receive when he or she is old and no longer able to work, and thus, the more secure one's life can be. This perception is further maintained and strengthened by the Chinese clan system; elderly people are the center of families, and family ethics emphasizes benevolent fathers and filial children, with expectations of respect for elders and care for juniors. However, not every family member carries the same responsibility; the strict patrilineal clan system results in a gender difference in providing care for elderly parents (Yang 1996). Rearing sons for old age and preparing funerals and send-offs are almost irrelevant to daughters; these roles are filled by sons, and this makes sons be seen as the most reliable "resources" for the support of the elderly (Mutharayappa 1997). Therefore, in order to avoid being ignored in old age, 
families often choose to have more children, given an environment where fertility is not controlled, to increase the likelihood of having male descendants. Also, since the traditional agricultural means of production relies heavily on investing in the labor force to increase production, and male labor is more advantageous than female in agricultural production, rural families prefer to have sons. As society develops, the meaning of "son" has changed to include both son and daughter, but it is still widely acknowledged that more children can provide better support for the elderly. Therefore, high fertility rate and son preference can be seen as rational responses to resource-limited contemporary society (Fei 1985; Li 1994).

Chinese society experienced dramatic changes over the last 50 years. The population transition, industrialization, urbanization, implementation of birth planning polices, and many other factors all contributed to smaller family size, changes in family structure, and the reconstruction of generational relations (Yang and Li 2009). Since the early 1980s, China has implemented strict birth planning policies in order to relieve the pressure of a large population. Over the past decades, China has made the demographic transition from a phase of "high fertility, high mortality, and high population growth" to a phase of "low fertility, low mortality, and low population growth." According to the Sixth National Population Census, the total fertility rate in China is around 1.45 (Guo 2011; Zhu 2012). There are now more families either with a few children or with only one child and many families with only daughters.

Some scholars hold the view that the decline in family size and the nuclearization of family will weaken the support and security family provided for the elderly. According to this perspective, in general, a decrease in the average number of children per family results in an increase in the number of old people that each child must take care of, and sometimes, one child has to look after four or even six old people. Even if the average income for the younger generation is continuously increasing, people's pace of life is increasing, and competition at work is getting fiercer too. Social care for the elderly will continue to grow, and family support will be weakened. Therefore, a decline in the number of children will lead to a decline in the life quality of elderly parents. Many empirical studies support this theory; for example, Pillai and Pei's research shows that having more children exerts significant positive influences on the generational support that the elderly receive and on their well-being (Pei and Pillai 1999). Guo and Zhang (1996) also suggest that, if other conditions stay constant, every additional child will result in another 39 yuan for the elderly parent each year. Liu's (2004) cross-gender study shows that the number of living daughters has a significant positive influence on elderly people's life quality but the number of living sons does not.

Some other scholars think that having more children does not necessarily bring about more support for old people (Zhou et al. 2012). The number of children only affects the quantity of potential caregivers, and other external conditions must be met for a potential caregiver to become an actual one, for example, "filial piety" to parents, certain modes of living, other social roles children play, and the children's socioeconomic status (Xia and Ma 1995). Many empirical studies have shown that the elderly people who have more children are more likely to think their children are not filial than is true for those with fewer children (Ye et al. 2007). Shuffling off responsibilities is more likely to happen among families with more children. For example, some research finds that 
having more children leads to more generational conflicts and economic confrontations, resulting in a low degree of satisfaction for the elderly (Watson and Kivett 1976). In addition, there is a trade-off between the quality and quantity of children; if the quality of children has a greater influence on parents' well-being, then having more children may also diminish the well-being of parents.

\section{Children quantity-quality trade-off effect in family support for the elderly}

According to Becker's "children quantity-quality tradeoff model," there is a positive relationship between family income and fertility-as income increases, the demand for children increases, and so does the demand for the quality of children. Parents are more willing to provide better care and education for children. Generally speaking, elasticity of demand in the quality of children is greater than that for the quantity of children (Becker 1960). In addition, an increase in the quality of children will increase the price of each child (the shadow price of quantity), and the increase in quantity will increase the cost of quality that is added to each child (the shadow price of quality). Therefore, an increase in quality is more expensive and will result in a decline in quantity demand. When there are more children in the family, the goods spending on each child (i.e., health care, education) is less, and the quality of children will decline (Becker 1992). Hanushek's study of American society proves that there is a positive relationship between the value of parents' time and the quality, rather than quantity, of children (Hanushek 1992). Gonzalez's (1991) research in the Philippines shows that in developing countries, there is also a trade-off between the quality and quantity of children.

The trade-off between the quality and quantity of children affects parents' quality of life in old age. In general, the greater the years of schooling, the higher the return rate of the human capital investment (Chiswiek 1978). Children from rural families who attend university and then work in urban centers have incomes far higher than any siblings that do agricultural work in the countryside. The increase in the years of schooling for children positively impacts the lives of elderly parents: such parents not only have better material conditions but also enjoy better life quality and heath conditions (Steelman 2002). Parents will be able to spend more resources on one child than on many, in order to improve that child's degree of education. Thus, children's educational attainment improves the life quality of elderly parents. This is the children quantity-quality trade-off in family support of elderly parents. But the question is, are parents capable of providing good education when they are only permitted to have one or two children, as is true when birth planning policies restrict the number of children? In an environment where resources are limited, what is the optimal education strategy for rural parents' life in old age when they cannot afford schooling for two or more children?

\section{Limited resources, optimal child-rearing strategy, and the life quality of elderly parents}

In evaluating children's enrollment opportunities and limited family resources, parents choose an optimal child-rearing strategy to ensure that at least one of their children will receive higher education so as to promote the socioeconomic status of the whole family and the parents' quality of life in old age. The parents in this study were born between 1933 and 1964, their children were born between 1956 and 1984, and these younger adults received an education between 1970 and 1990. In the childbearing period of these 
mothers, the birth planning policies were not strictly implemented. Only part of the social upbringing fees were paid, and many rural areas still had a relatively high fertility rate. ${ }^{1}$ Further, by the time these children reached school age, educational investment in rural areas was still determined by the family and also restricted by household income (Zeng 1998). Since China did not have an education system fully sponsored by the state, and it was not until 2001 that the elementary education received financial support from county governments (Qiao et al. 2005), education expenditures for most country governments came from "san tiwu tong. ${ }^{2 "}$ Villages in poor areas required that families share more of the cost of education (Hannum 2003). The resources children received from their families were limited both by the family's total resources and the number of children. Family resources directly influence children's educational attainment because families must have sufficient income to pay children's tuition fees. If the number of siblings is great, the time between pregnancy intervals is short, and resources are diluted, then children are unlikely to receive high levels of education (Blake 1981; Downey 1995).

In addition, the enrollment rate for children from rural areas is significantly lower than that from urban areas. ${ }^{3}$ In rural areas, the benefits from a child's receiving education are relatively uncertain; the parents are unable to predict which child may perform better at school, and they do not know which child is most likely to finish school successfully. Moreover, parents from rural families typically receive little education themselves, and their attitudes towards their children's education will rely largely on their children's will and performance in school. In most cases, they will support the child who has a better school performance. If other children do not want to go to school, or are unlikely to be enrolled for a higher level of education, their parents will allow them to drop out of school to work and help the family. However, in situations where more than one child has good performance at school, limited family resources will still encourage parents to choose one to continue education and others to drop out. Zhu Jingyi et al. analyze data from Taiwan and find that, if the family collects all family resources, it will more likely sacrifice educational opportunities for older children and use the resources to support younger children (Chu et al. 2007).

How will an optimal child-rearing strategy affect parents' life quality at old age? Altruism corporate group theory posits that, as an economic community, children from the same family will choose to divide their labor at the minimum cost so as to reach Pareto optimality in allocating resources. In other words, children who are better off provide financial care for the elderly, others provide care for parents' daily lives, and in this way, the welfare of the whole family is maximized (Becker 1974). According to the optimal child-rearing strategy, those children who received the most education are likely to have better careers and incomes, and therefore, they can support their parents financially; children who received less education and remained in rural villages look after their parents and provide more emotional comfort. This division of responsibility improves the life quality of elderly parents.

\section{Fertility strategy and the life quality of the elderly in rural areas: categorization and hypothesis \\ Fertility strategy and categorization of periods of old age}

The discussion above clearly shows that we need further and deeper empirical research to understand the relationship between fertility strategy and the life quality of elderly 
parents in rural areas in the contemporary context. The quality and quantity of children are two important aspects in which fertility strategy affects the life quality of parents as they age and also key factors in evaluating whether more children really do bring more blessings. Upon distinguishing the quantity and gender of children, we further categorize the years of schooling into average years of schooling, lowest years of schooling, and highest years of schooling. When parents of childbearing age consider how they hope to be provided for as they age, they may pursue one of three fertility and education strategies in order to secure their improved quality of life in their golden years (Table 1).

The first fertility strategy is give birth to more children. These parents fully accept the idea of "more children bring more blessings," choosing to have more children rather than ensuring that they can provide an education for all of their children. Further, their fertility strategy is not only about the number of children but also about the gender of children, and therefore, we further categorize the children according to their gender and investigate whether the number of sons and the number of daughters lead to different outcomes in quality for the elderly. This is a general strategy applied in the current literature (Chen and Du 2002; Geng 2013), and therefore, comparisons can be made.

The second fertility strategy is emphasize children's education. Because of the tradeoff between the quantity and quality of children, families who want to ensure their children's education will have relatively fewer children, and this strategy results in fewer and better births. Families who see education as valuable and therefore work to ensure that their children go to school have children whose numbers of years of education received are higher (relative to other family types). In order to identify the increase in the average years of schooling caused by the number of years of schooling that certain children from one family receive, we introduce the variable of lowest years of schooling, which captures parents' attitudes towards education for all children and effectively differentiates parents in this category from those in the first category. ${ }^{4}$

The third fertility strategy is optimize child-rearing. These parents want to have more children and realize the importance of education, but because of limited family resources, they cannot afford to send all children to school. They therefore select one child who receives the education investment. Optimal child-rearing of children also leads to fewer and better births - to limit the quantity of children and instead focus on nurturing fewer children. From the perspective of providing family care for elderly parents, parents likely choose this strategy by evaluating the relationship between children's years of education and the life quality of the elderly.

Table 1 Three fertility strategies adopted by parents

\begin{tabular}{|c|c|c|c|}
\hline First strategy & \multicolumn{2}{|l|}{ Second strategy } & Third strategy \\
\hline To give birth to & \multicolumn{2}{|c|}{ To emphasize children's education } & Optimal child-rearing \\
\hline Quantity of children & Average years of schooling & Lowest years of schooling & Highest years of schooling \\
\hline Number of sons & $\begin{array}{l}\text { Average years of schooling } \\
\text { of sons }\end{array}$ & $\begin{array}{l}\text { Lowest years of schooling } \\
\text { of sons }\end{array}$ & $\begin{array}{l}\text { Highest years of schooling } \\
\text { of sons }\end{array}$ \\
\hline $\begin{array}{l}\text { Number of } \\
\text { daughters }\end{array}$ & $\begin{array}{l}\text { Average years of schooling } \\
\text { of daughters }\end{array}$ & $\begin{array}{l}\text { Lowest years of schooling } \\
\text { of daughters }\end{array}$ & $\begin{array}{l}\text { Highest years of schooling } \\
\text { of daughters }\end{array}$ \\
\hline
\end{tabular}


Current research on the life quality of the elderly ignores the different stages of old age. In different stages, family members will employ different strategies, which in turn will have different impacts on parents' life quality. We categorize the elderly into different life stages according to age. The World Health Organization suggested that China define people over 60 as elderly. Chinese Geriatric Conference proposed that China define people over 60 as elderly, with 49-59 years of age defined as "young old," 6089 years of age as "old," and over 90 years old as "oldest old." This research categorizes the elderly population into three categories: $49-59$ as early old, 60-69 as middle old, and over 70 as old old.

\section{Research hypotheses}

In traditional Chinese families, the fact that the elderly hold the central position in the family is key to the "more children bring more blessing" phenomenon. Elderly parents have power over their grown-up children, which results in the children having a strong emotional attachment to their parents, being wholeheartedly devoted to caring for their parents, and therefore preferring a larger family (Fei 1985). Parents maintain their power and authority largely as a result of their control of family property, the fact that the family is the basic unit of production and consumption, and the strengthening of Confucian morality (Shi \& Yang 2012). In the twentieth century, China experienced a reorganization of politics and society, rapid industrialization and urbanization, and construction of civil society-all of which broke the social conditions that created and maintained the old family order with the elderly at the center-and thus, their power and authority in the family has been weakened (Chen 1998).

The declining authority of the elderly in the family strongly influences children's care for them. In situations where parental authority is largely undermined, children are economically independent and have less filial affection. As a result, simply increasing the number of children does not necessarily improve the life quality of elderly parents. In the transitional period, it is quite common in rural areas for parents to have to build a house or buy an apartment and pay for expensive betrothal gifts in order to help their sons get married. The outflow of rural labor has changed the family structure and increased the number of nuclear families. ${ }^{5}$ Children are separated from their elderly parents when they stay in the city after graduating from the university or when they take a job elsewhere, and this also undermines sons' capability and willingness to provide care for their parents (Zhu and Xu 1992). In addition, rural women tend to marry into families with better living conditions. Many women choose to marry men who live in the urban areas, resulting in a further increase in the cost of marriage for men in rural areas. But this will also in turn improve daughters' ability to provide for their parents. Considering these factors, we raise our first hypothesis.

\section{Hypothesis 1}

In contemporary rural areas, an increase in the number of children, particularly the number of sons, will significantly lower the life equality of elderly parents.

Care provision provided by children is decided by their capability and their willingness. To some extent, according to the "adverse selection principle," parents' choice of having more children is made at the cost of better education for each child, and as a result, the care they receive from their children is restricted by children's education. An 
alternative strategy is to have fewer children and invest more in children's education. The investment payback from education has increased with the development of the Chinese market economy beginning in 1992 and will continue to increase. Therefore, an increase in the years of schooling will improve children's capability to provide care for their parents.

Generational exchange, a general social exchange, is the redistribution of resources based on social morality, emotional support, and the maintenance of public justice. There is a causal relationship between parents' investment in children and children's care provision. Parents' investment in children influences children's care provision through the collective view of obligation; children who receive better education because of parents' sponsorship will be more motivated to provide care for their parents, since they have spent more of their parents' money. Additionally, a male-dominated population with a higher level of education finds a job in the city, which to some extent undermines the relationship between sons' education and life quality of elderly parents. According to the above analysis, we put forward our second hypothesis.

\section{Hypothesis 2}

An increase in children's years of schooling significantly improves the life quality of parents, and an increase in daughters' years of schooling has a more obvious effect.

Parents hope that all of their children can receive a good education, but when parents have limited resources, they resort to one of two strategies: (1) equal development, whereby they provide all children with the same, but relatively lower, level of education and (2) particular education, by telling some of their children to drop out of school and support the family. Generally speaking, the second strategy can better improve the family's economic and social status. Children who are selected to receive better education can not only have better personal development but also help their siblings, and all of these actions contribute to the improvement of the parents' quality of life.

\section{Hypothesis 3}

The life quality of elderly parents will increase more when children achieve the highest years of schooling, as compared to the average years of schooling.

In different periods of old age, parents' health conditions, self-care ability, and relationship with their children differ, and children's years of schooling have different levels of influence on parents' life quality. In general, when parents are in their early-old period, they have better health conditions and will have more contact with their daughters; they may even live with their daughters. In this case, the years of schooling for daughters has a more significant effect on parents' life quality at this period. However, the custom of living with the husband still remains in the rural area, ${ }^{6}$ and in the oldold period of old age, parents will normally choose to stay with their sons, and therefore, the years of schooling of sons become the key factor in influencing parents' life quality.

\section{Hypothesis 4}

In the early-old period, daughter's years of schooling has a more significant effect on the life quality of elderly parents compared to that of the son; but when parents grow 
older, the impact of the son's years of schooling will gradually exceed that of a daughter's.

In hypothesis 1 , we simply differentiate families with more children from families with fewer children to investigate if more children bring better quality of life; we do not explain the internal mechanism. In hypothesis 2, because of the trade-off between the quantity and quality of children, families with more children and families with fewer children are lumped together, and target families are categorized according to the education level of their children. If the test supports hypotheses 1 and 2, we can conclude that social economic development has broken the traditional family order, which has been characterized by "more children bring more well-being." And the strategy of "fewer and better birth," which has been promoted by the family planning policy, will gradually become an alternative fertility strategy. Hypothesis 3 is a further test of the effect of children's education in resourcelimited rural areas.

We use the graph to demonstrate our first three hypotheses (Fig. 1). The two lines show the relationship between years of schooling for son/daughter and parents' life quality. Families with more children appear more frequently in the leftbottom part of the graph, in which both the years of schooling for children and parents' life quality are relatively low. Families with fewer children are spotted in the upper-right corner where children's years of schooling and parents' life quality are higher. If we put sons and daughters together, we can see that increasing the number of children will not improve parents' life quality in old age; the years of schooling of children has a positive effect on parents' life quality at old age. If we put families with more children and with fewer children together, we can observe a more obvious effect of daughters' years of education on parents' life quality.

(Note: the oval in dotted lines in the bottom-left corner shows the distribution of families with more children, and the life quality of parents from these families is less affected by the gender distribution of their children. The oval in the upperright corner illustrates families with fewer children, and because they have fewer children, the gender distribution of those children has a significant influence on parents' life quality at old age.)

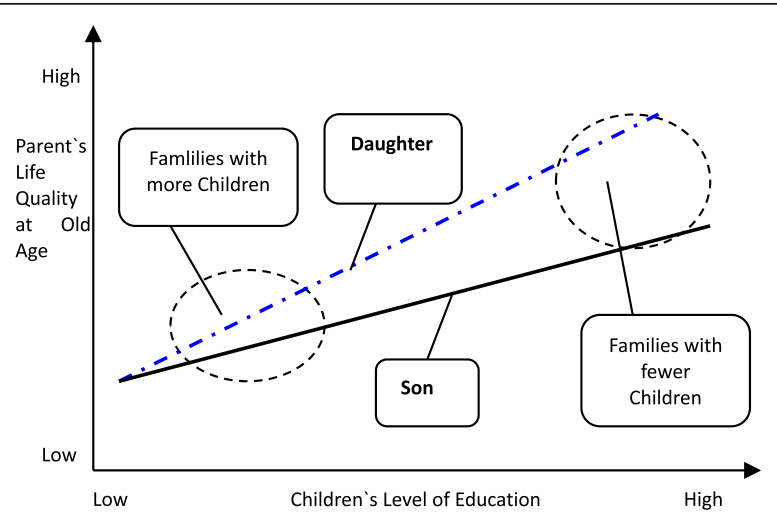

Fig. 1 Number of children, years of schooling, and parents' life quality at old age 


\section{Research design and the data}

\section{Sampling}

This empirical research was conducted from July 20, 2013 to July 28, 2013, in Hubei province. The sample includes 1500 families. Hubei province is a main agricultural province in China and is an important and representative province of Central China. It is located at the intersection of the north and the south; the western part of Hubei is mountainous while the eastern part is mainly plains and hills. Multiethnic groups live in Hubei resulting in a multiethnic cultural environment. Recent adjustments in national policies, particularly the implementation of the policies to benefit farmers, of the rise of Central China Plan, and of expanding domestic demand, have contributed to Hubei's rapid economic development and made it an appropriate case for this study.

This study used stratified samples. We first ranked the counties in Hubei according to their fertility rate and then applied point-quarter sampling to choose four representative counties. Following this, we allocated sample numbers according to the population distribution of each county. Considering that different townships have different economic and geographic environments, we chose one relatively rich township and one relatively poor township from each county, picking four villages from each township randomly, to result in 50 random households from each village. Each household was given one copy of the questionnaire. Because this research investigates parents who are older than childbearing age, we only investigated households where wives were over 49. ${ }^{7}$ The respondents could be either the husband or the wife. We sent out 1500 questionnaires and received 1489 valid responses. The distribution of this sample is as follows: $87 \%$ of the respondents were aged between 50 and 80; $36 \%$ were male; $33.5 \%$ were illiterate, $32.1 \%$ indicated primary school was their highest educational achievement, 22.4\% indicated junior high school was their highest educational achievement, and $9.5 \%$ indicated they had graduated from senior high school or higher; $2.3 \%$ of the couples have one daughter, $6.5 \%$ have one son, $4.4 \%$ have two daughters, $9.6 \%$ have one daughter and one younger son, $8.7 \%$ have one son and a younger daughter, ${ }^{8} 10 \%$ have two sons, $26.1 \%$ have three children, and $32.1 \%$ have four children or more; and $34.3 \%$ live with their children. From the geographical environment, we can see that $60.6 \%$ of the households are located on plains, $15.2 \%$ live in the hilly areas, and $24.1 \%$ live in the mountainous areas.

Before modeling, we made great efforts to clean up data: we excluded families with no children in order to make sure valid comparisons could be made; we also excluded families with wives aged below 49. Only a small number of cases were deleted (2.4\%); this resulted in a sample of 1454 households. Of the respondents, 759 respondents were between 49 and 59 years old, 530 were between 60 and 69,

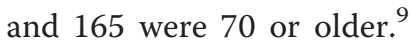

\section{Variable measurement and endogeneity Variable measurement}

"Life quality" as a research area has existed for half a century and is studied by various disciplines including medicine, psychology, economics, and sociology. Although there is no single definition, systematic indexing, or evaluation principles, generally speaking, scholars tend to agree that it is a general index used to evaluate a population's living 
conditions from the perspective of social development and is more inclusive than "standard of living" (Wu 2002). Life quality should include both subjective feeling and objective evaluation (Arnold 1991). Healthy physical condition is the natural foundation for human existence and development, and the material conditions of life, which provide its material foundation, is the premise by which life quality is evaluated. People's evaluation of life is shaped by their objective living conditions and by their personal characteristics, frame of reference, cultural environment, and many others (Lin et al. 1987; Lu and Wei 1992). In this research, the life quality of these elderly in rural areas includes their health condition, economic status, living environment, and emotional comfort during a certain period of time. When measuring life quality, this study adopted a common method applied by most current studies to include both the objective living conditions and subjective satisfaction and to combine the supply of material goods and how it meets people's demand. Firstly, respondents' health condition is measured by self-evaluated health measurement and physical mobility. Self-evaluation requires that the respondent uses the peer group of the respondents as the frame of reference, and respondents are asked to rate themselves from 1 to 4; a higher score indicates a better self-evaluated health condition. ${ }^{10}$ Secondly, respondents' economic status is evaluated by their self-evaluation according to their economic status in the village and their daily consumption. Self-evaluation of economic status asks respondents to rate their own economic status by referring to the community they live in. Moreover, considering that in rural areas meat consumption is still an important economic index in measuring people's life quality, we added another objective index "money paid for meat consumption in recent half month." Thirdly, higher life quality requires a better living environment, including housing and the facilities in the home. However, living environment is influenced by local customs. For example, some families are not well off but will borrow a large amount of money to build a house when their child marries or to compete with their neighbors. But facilities in the house suggest the current economic status of the household. Here, we choose flooring building materials, including (1) rammed earth flooring, (2) brick flooring, (3) cement flooring, (4) ceramic tile flooring, (5) stone flooring, and (6) wooden flooring," and value them 1-6 accordingly, to evaluate economic status. Apart from these, we also chose "the main energy for cooking" to describe the current living environment. Families using "firewood or straw" live in a poorer environment compared to those using "gas or electricity." Fourthly, emotional comfort is estimated through the frequency of communication between parents and children, and an alternative variable is "whether to live with children."

The core independent variable is as follows:

Families that choose to have more children are evaluated in the model by the number of living children and by the difference between the number of daughters and sons. Families that emphasize children's education are examined through the average years of children's schooling and the lowest years of children's schooling. Parents who emphasize education equally among children will influence the average years of schooling. A rise in years of schooling of particular children will also influence the average years of schooling among all children in the family, so we introduced the lowest years of schooling. When having more children and parents can only select to educate some of their children, the highest years of children's education will show greater variation. 
In the regression that takes the number of children as the independent variable, if the dependent variable is children's average years of schooling, then the regression coefficient $=0.571, p$ value $=0.000$; if the dependent variable is children's lowest years of schooling, then the regression coefficient would be $0.905, p$ value $=0.000$; and if children's highest years of schooling is the dependent variable, the regression coefficient $=$ -0.071 , and $p$ value $=0.230$. We can see that in this research, there is a trade-off between the number of children and children's average years of schooling and the number of children will also influence parents' decision about whether or not to let some of their children drop out of school. However, the number of children cannot affect the children's highest years of schooling directly; in other words, parents cannot decide on children's highest years of schooling by manipulating the number of children-they can only collect their resources and send their children to school.

This model also controls for personal characteristics and geographical environment of the elderly. Human capital, political capital, and social capital all have important impacts on life quality, and in this study, human capital is estimated by age and years of schooling, political capital by their political status, and social capital by the number of their siblings. Because the life quality of the elderly and the influence that sons and daughters have on their parents' life are closely related to the economy, the social development, and the cultural traditions of the local community, we control for the type of land in the elderly's communities. In addition, considering that the children of these respondents were born from the 1950s to the 1980s-influenced by political movements, economic development, and many other factors-and have great generational variance that significantly affected children's educational opportunities and parents' life quality, we take children's year of birth as a dummy variable when considering the relation between fertility decision and elderly parents' life quality. For example, if the family has children that were born in the 1950s, then it is valued 1, and other families would be valued 0; if the family has children that were born in the 1960 s, then it is valued 1 , others 0 ; the rest are the same.

\section{Endogeneity}

Endogeneity comes from three sources: firstly, measurement error, that is to say that a correlation exists between the number of children, children's years of schooling, and measurement error. ${ }^{11}$ The second source is simultaneity. Our research design was structured to avoid simultaneity. It is unlikely that parents' current life quality is the cause of their earlier decision about the number of children or children's years of schooling. Fertility decision is a predetermined variable, and all children in this sample have completed their studies or at least are not in school. The third source is omitted variables. Variables that may result in bias are those related to the quantity of children, years of education, and at the same time with parents' life quality. For example, it is possible that young parents may have income levels and quality of life levels that, at that time, would affect a fertility decision and their ability to invest in children's education and thus affect their current life quality. In order to avoid omitted variable bias, we use the following method: firstly, we restrict our sample to rural areas. Children from the object families were born between 1956 and 1984, during which time rural residents were largely peasants, and differences in income were not obvious. Secondly, we try to control for the variables that would reflect the living standards of the time and affect current life quality according to existing research. Examples include years of 
education of the elderly, whether or not they are party members, number of siblings, and families' geographical environment. During the time when work points ${ }^{12}$ were decided by the number of laborers, the number of parents' siblings reveals the living standards of the parents at that time. Thirdly, the child planning policy was not strictly implemented in the 1960s or 1970s, and few people in rural areas ran tests to determine the sex of the child in utero, so gender can be regarded as random. In the model, we differentiate the number of daughters from that of sons. Generally speaking, children's highest years of schooling is unlikely to be controlled by parental choice alone; even if parents strongly hope that their children will receive higher education, in situations where education resources are limited, children's highest years of education is largely decided by internal factors including their IQ and their work efforts, as well as external factors such as local educational resources and enrollment rates.

\section{Number of children and its impact on elderly people's life quality in rural areas}

Health condition is an important indicator of elderly people's life quality. Regression ${ }^{13}$ shows that controlled variables like elderly people's years of schooling, age, political status, number of siblings and regional characters, and number of living children all have a significant negative impact on parents' self-assessment of health and physical mobility and both the number of sons and the number of daughters have negative impact. That is to say, the more children they have, the worse parents' health conditions are compared to people of the same age who have no children.

Economically, the number of living children has a significant negative impact on parents' relative economic status, but surprisingly, the number of sons and daughters alone does not have a significant effect. As the number of children increases, regardless of gender, parents' economic status declines. Specifically, an increase in the number of sons reduces elderly parents' consumption of meat, while an increase in the number of daughters has no significant impact on parents' meat consumption. An increase in the total number of children has a significant negative effect on parents' living environment-for both past and present-and the increase in the number of either sons or daughters decreases the quality of parents' living environment. As for living patterns, Guo's (2002) research shows that whether or not to have children is significant to parents' life quality but the exact number of children is not. In order to further test this hypothesis, we include the number of sons and the number of daughters separately in the model. We find that the more daughters, the higher the probability that parents live with their children, but the number of sons does not have a similar effect. This further demonstrates that Chinese preference for boys is not a pure preference for boys but a preference based on the fact that they have both boys and girls (Table 2).

\section{Emphasizing children's education and its influence on elderly parents' life quality in rural areas}

We use the average years of children's schooling and the lowest years of schooling to indicate how parents emphasize children's education. When there is a trade-off between the quantity and quality of children, generally speaking, parents who emphasize children's education will choose to have fewer children. Therefore, the above two indicators are also used to measure the "fewer and better birth" policy and to use the 
Table 2 Number of sons and daughters and their influence on life quality of elderly parents

\begin{tabular}{|c|c|c|c|c|c|c|c|}
\hline \multirow[t]{3}{*}{ Variables } & \multicolumn{2}{|c|}{ Health condition } & \multicolumn{2}{|l|}{ Economic status } & \multicolumn{2}{|c|}{ Living environment } & \multirow{2}{*}{$\begin{array}{l}\text { Living } \\
\text { pattern } \\
\text { R7 }\end{array}$} \\
\hline & R1 & R2 & R3 & R4 & R5 & R6 & \\
\hline & $\begin{array}{l}\text { Self- } \\
\text { assessment }\end{array}$ & $\begin{array}{l}\text { Physical } \\
\text { mobility }\end{array}$ & $\begin{array}{l}\text { Self-assessment of } \\
\text { relative economic } \\
\text { status }\end{array}$ & $\begin{array}{l}\text { Meat } \\
\text { consumption }\end{array}$ & Flooring & $\begin{array}{l}\text { Cooking } \\
\text { energy }\end{array}$ & $\begin{array}{l}\text { Living } \\
\text { with } \\
\text { children }\end{array}$ \\
\hline $\begin{array}{l}\text { Number of } \\
\text { living sons }\end{array}$ & $\begin{array}{l}-.077^{* * * *} \\
(.026)\end{array}$ & $\begin{array}{l}-.045^{*} \\
(.025)\end{array}$ & $-.033(.031)$ & $\begin{array}{l}-.108^{* *} \\
(.045)\end{array}$ & $\begin{array}{l}-.119^{* * *} \\
(.028)\end{array}$ & $\begin{array}{l}-.307^{* * *} \\
(.072)\end{array}$ & $.124(.075)$ \\
\hline $\begin{array}{l}\text { Number of } \\
\text { living } \\
\text { daughters }\end{array}$ & $\begin{array}{l}-.057^{* * *} \\
(.020)\end{array}$ & $\begin{array}{l}.050^{* * *} \\
(.005)\end{array}$ & $-.029(.024)$ & $-.009(.033)$ & $\begin{array}{l}-.074^{* * *} \\
(.022)\end{array}$ & $\begin{array}{l}-.202^{* * *} \\
(.054)\end{array}$ & $\begin{array}{l}.101^{*} \\
(.057)\end{array}$ \\
\hline \multicolumn{8}{|c|}{ Personal characteristics of respondents } \\
\hline $\begin{array}{c}\text { Years of } \\
\text { schooling }\end{array}$ & $\begin{array}{l}.017^{* * *} \\
(.005)\end{array}$ & $\begin{array}{l}.012^{* *} \\
(.005)\end{array}$ & $.040^{* * *}(.007)$ & $.018^{* *}(.009)$ & $\begin{array}{l}.025^{* * *} \\
(.006)\end{array}$ & $\begin{array}{l}.080^{* * *} \\
(.015)\end{array}$ & $\begin{array}{l}.027^{*} \\
(.015)\end{array}$ \\
\hline Age & $\begin{array}{l}-.018^{* * *} \\
(.003)\end{array}$ & $\begin{array}{l}-.032^{* * *} \\
(.003)\end{array}$ & $-.021^{* * *}(.004)$ & $\begin{array}{l}-.015^{* * *} \\
(.005)\end{array}$ & $\begin{array}{l}-.026^{* * *} \\
(.004)\end{array}$ & $\begin{array}{l}-.040^{* * *} \\
(.009)\end{array}$ & $\begin{array}{l}-.098^{* * *} \\
(.010)\end{array}$ \\
\hline $\begin{array}{l}\text { Party } \\
\text { membership }\end{array}$ & $\begin{array}{l}.158^{* *} \\
(.077)\end{array}$ & $\begin{array}{l}.108 \\
(.075)\end{array}$ & $.247^{* * *}(.093)$ & $.200^{*}(.118)$ & $\begin{array}{l}.059 \\
(.084)\end{array}$ & $.201(.215)$ & $\begin{array}{l}-.240 \\
(.226)\end{array}$ \\
\hline $\begin{array}{l}\text { Number of } \\
\text { siblings }\end{array}$ & $.001(.011)$ & $\begin{array}{l}.014 \\
(.011)\end{array}$ & $-.003(.013)$ & $.036^{* *}(.019)$ & $\begin{array}{l}-.011 \\
(.012)\end{array}$ & $\begin{array}{l}-.050 \\
(.031)\end{array}$ & $\begin{array}{l}-.043 \\
(.032)\end{array}$ \\
\hline $\begin{array}{l}\text { Mountainous } \\
\text { areas }\end{array}$ & $\begin{array}{l}.111^{* *} \\
(.055)\end{array}$ & $\begin{array}{l}.060 \\
(.053)\end{array}$ & $.091(.066)$ & $-.045(.088)$ & $\begin{array}{l}.134^{* *} \\
(.060)\end{array}$ & $\begin{array}{l}-.825^{* * *} \\
(.149)\end{array}$ & $\begin{array}{l}-.677^{* * *} \\
(.163)\end{array}$ \\
\hline 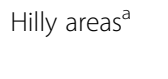 & $\begin{array}{l}-.116^{* *} \\
(.059)\end{array}$ & $\begin{array}{l}-.111^{* *} \\
(.057)\end{array}$ & $.112(.071)$ & $.392^{* * *}(.103)$ & $\begin{array}{l}-.087 \\
(.064)\end{array}$ & $\begin{array}{l}-.736^{* * *} \\
(.159)\end{array}$ & $\begin{array}{l}-.029 \\
(.162)\end{array}$ \\
\hline Intercept & $\begin{array}{l}4.378^{* * *} \\
(.211)\end{array}$ & $\begin{array}{l}6.261^{* * *} \\
(.205)\end{array}$ & $3.904^{* * *}(.256)$ & $\begin{array}{l}4.785^{* * *} \\
(.352)\end{array}$ & $\begin{array}{l}4.748^{* * *} \\
(.231)\end{array}$ & $\begin{array}{l}3.450^{* * *} \\
(.591)\end{array}$ & $\begin{array}{l}5.032^{* * * *} \\
(.626)\end{array}$ \\
\hline Valid sample & 1454 & 1454 & 1454 & 1454 & 1454 & 1454 & 1454 \\
\hline$F$-value & $15.113^{* * *}$ & $27.183^{* * *}$ & $18.203^{* * *}$ & $7.752^{* * *}$ & $24.11^{* * *}$ & $229.768^{* * *}$ & $159.571^{* * *}$ \\
\hline$R^{2}$ & .076 & .128 & .090 & .077 & .116 & .192 & .141 \\
\hline
\end{tabular}

highest years of schooling of sons and daughters to indicate parents' resource concentration strategy. ${ }^{14}$

From the perspective of health conditions, children's average years of schooling has a significant positive impact on elderly parents' health conditions; however, it is the daughter's average years of schooling that has a significant positive impact on both elderly parents' self-assessment and physical mobility while sons' average years of schooling has no significant influence. Considering economic status, an increase in children's average years of schooling will improve elderly parents' relative economic status in the village, whether for sons or daughters. Also, there is a significant positive relationship between children's years of schooling and elderly parents' meat consumption. In terms of living environment, the higher children's average years of schooling, the better flooring materials, and parents are more inclined to use gas or electricity instead of firewood. By examining sons and daughters separately, we find that sons' average years of schooling has no significant impact on elderly parents' flooring materials or cooking energy while daughters' average years of schooling does and the significance level is at $1 \%$. Speaking of living patterns, the increase in children's average years of schooling increases elderly parents' probability of living alone rather than with their children. A 
possible explanation is that children who receive higher years of schooling are more likely to work in other places other than their hometown and parents are less likely to live with them (see Table 3).

For different age groups, daughter and son's average years of schooling influences elderly people's life quality differently. In parents' early-old, middle-old, and old-old periods, children's average years of schooling has a significant and positive impact on parents' relative economic status. However, as the parents' age grows, the effect of sons' average years of schooling increases while that of the daughters' decreases, and for parents of 70 and above, daughters' average years of schooling no longer has a significant effect. It is only during parents' early-old period that daughters' average years of

Table 3 Average years of schooling of daughters and sons and their impact on elderly people's life quality in rural areas

\begin{tabular}{|c|c|c|c|c|c|c|c|}
\hline \multirow[t]{3}{*}{ Variables } & \multicolumn{2}{|c|}{ Health condition } & \multicolumn{2}{|c|}{ Economic status } & \multicolumn{2}{|c|}{ Living environment } & \multirow{2}{*}{$\begin{array}{l}\text { Living } \\
\text { pattern } \\
\text { R7 }\end{array}$} \\
\hline & $\mathrm{R} 1$ & $\mathrm{R} 2$ & R3 & R4 & R5 & R6 & \\
\hline & $\begin{array}{l}\text { Self- } \\
\text { assessment }\end{array}$ & $\begin{array}{l}\text { Physical } \\
\text { mobility }\end{array}$ & $\begin{array}{l}\text { Relative } \\
\text { economic } \\
\text { status }\end{array}$ & $\begin{array}{l}\text { Meat } \\
\text { consumption }\end{array}$ & Flooring & $\begin{array}{l}\text { Cooking } \\
\text { energy }\end{array}$ & $\begin{array}{l}\text { Living } \\
\text { with } \\
\text { children }\end{array}$ \\
\hline $\begin{array}{l}\text { Sons' average years } \\
\text { of schooling }\end{array}$ & $.006(.011)$ & $\begin{array}{l}-.005 \\
(.011)\end{array}$ & $.051^{* * *}(.013)$ & $-.028(.018)$ & $\begin{array}{l}.017 \\
(.012)\end{array}$ & $.027(.031)$ & $\begin{array}{l}-.101^{* * *} \\
(.033)\end{array}$ \\
\hline $\begin{array}{l}\text { Daughters' average } \\
\text { years of schooling }\end{array}$ & $\begin{array}{l}.021^{* *} \\
(.011)\end{array}$ & $\begin{array}{l}.028^{* *} \\
(.011)\end{array}$ & $.064^{* * *}(.013)$ & $.025(.017)$ & $\begin{array}{l}.047^{* * *} \\
(.012)\end{array}$ & $\begin{array}{l}.127^{* * *} \\
(.031)\end{array}$ & $.014(.031)$ \\
\hline \multicolumn{8}{|c|}{ Personal characteristics of respondents } \\
\hline Years of schooling & $\begin{array}{l}.014^{* *} \\
(.007)\end{array}$ & $\begin{array}{l}.010 \\
(.007)\end{array}$ & $.030 * * *(.008)$ & $.014(.010)$ & $\begin{array}{l}.013^{*} \\
(.007)\end{array}$ & $\begin{array}{l}.068^{* * *} \\
(.018)\end{array}$ & $.019(.019)$ \\
\hline Age & $\begin{array}{l}-.018^{* * *} \\
(.007)\end{array}$ & $\begin{array}{l}-.029^{* * *} \\
(.007)\end{array}$ & $\begin{array}{l}-.021^{* * *} \\
(.008)\end{array}$ & $\begin{array}{l}-.021^{* *} \\
(.010)\end{array}$ & $\begin{array}{l}-.029^{* * *} \\
(.007)\end{array}$ & $\begin{array}{l}-.058^{* * *} \\
(.019)\end{array}$ & $\begin{array}{l}-.098^{* * *} \\
(.020)\end{array}$ \\
\hline Party membership & $.172^{*}(.094)$ & $\begin{array}{l}.152^{*} \\
(.093)\end{array}$ & $.127(.111)$ & .139 (.135) & $\begin{array}{l}.034 \\
(.101)\end{array}$ & $.168(.262)$ & $.126(.275)$ \\
\hline Number of siblings & $.000(.014)$ & $\begin{array}{l}.007 \\
(.014)\end{array}$ & $-.006(.016)$ & $.046^{* *}(.022)$ & $\begin{array}{l}-.028^{* *} \\
(.015)\end{array}$ & $\begin{array}{l}-.066 \\
(.038)\end{array}$ & $.006(.040)$ \\
\hline Mountainous areas & $.073(.060)$ & $\begin{array}{l}.008 \\
(.059)\end{array}$ & $.067(.070)$ & $-.104(.091)$ & $\begin{array}{l}.077 \\
(.063)\end{array}$ & $\begin{array}{l}-.1 .030^{* * *} \\
(.163)\end{array}$ & $\begin{array}{l}-.491^{* * *} \\
(.175)\end{array}$ \\
\hline Hilly areas & $\begin{array}{l}-.221^{* * *} \\
(.077)\end{array}$ & $\begin{array}{l}-.158^{* *} \\
(.076)\end{array}$ & $.046(.090)$ & $.382^{* * *}(.125)$ & $\begin{array}{l}-.220^{* * *} \\
(.082)\end{array}$ & $\begin{array}{l}-.986^{* * *} \\
(.209)\end{array}$ & $\begin{array}{l}-.049 \\
(.218)\end{array}$ \\
\hline \multicolumn{8}{|l|}{ Birth year of children } \\
\hline $1950 \mathrm{~s}$ & $.273(.187)$ & $\begin{array}{l}-.208 \\
(.185)\end{array}$ & $.125(.220)$ & $-.091(.297)$ & $\begin{array}{l}-.005 \\
(.200)\end{array}$ & $\begin{array}{l}-.137 \\
(.555)\end{array}$ & $\begin{array}{l}1.222^{* *} \\
(.544)\end{array}$ \\
\hline $1960 s$ & $\begin{array}{l}-.220^{* *} \\
(.088)\end{array}$ & $\begin{array}{l}-.218^{* *} \\
(.087)\end{array}$ & $.022(.104)$ & $.047(.144)$ & $\begin{array}{l}-.057 \\
(.094)\end{array}$ & $\begin{array}{l}-.075 \\
(.243)\end{array}$ & $.169(.280)$ \\
\hline $1970 s$ & $\begin{array}{r}-.003 \\
(.079)\end{array}$ & $\begin{array}{l}.067 \\
(.078)\end{array}$ & $.014(.093)$ & $.006(.124)$ & $\begin{array}{l}.103 \\
(.084)\end{array}$ & $.084(.214)$ & $\begin{array}{l}-.351 \\
(.231)\end{array}$ \\
\hline 1980s & $\begin{array}{l}-.096 \\
(.071)\end{array}$ & $\begin{array}{l}-.024 \\
(.070)\end{array}$ & $-.049(.083)$ & $-.118(.111)$ & $\begin{array}{l}.027 \\
(.075)\end{array}$ & $\begin{array}{l}-.424^{* *} \\
(.198)\end{array}$ & $\begin{array}{l}-.167 \\
(.213)\end{array}$ \\
\hline Intercept & $\begin{array}{l}4.075^{* * *} \\
(.417)\end{array}$ & $\begin{array}{l}5.858^{* * *} \\
(.441)\end{array}$ & $\begin{array}{l}2.888^{* * *} \\
(.489)\end{array}$ & $\begin{array}{l}4.604^{* * *} \\
(.646)\end{array}$ & $\begin{array}{l}4.187^{* *} \\
(.445)\end{array}$ & $\begin{array}{l}2.897^{* * *} \\
(1.176)\end{array}$ & $\begin{array}{l}6.160 \\
(1.229)\end{array}$ \\
\hline Valid sample & 994 & 994 & 994 & 994 & 994 & 994 & 994 \\
\hline F-value & $8.845^{* * *}$ & $14.220^{* * *}$ & $13.136^{* * *}$ & $4.466^{* * *}$ & $11.130^{* * *}$ & $163.83^{* * *}$ & $121.824^{* * *}$ \\
\hline$R^{2}$ & .094 & .148 & .138 & .093 & .120 & .203 & .161 \\
\hline
\end{tabular}

Note: (1) Models R1, R2, R3, R4, and R5 are linear regression models; models R6 and R7 are binomial logistic regression; the output reports for the goodness of fit is Nagelkerke $R^{2}$; and the report for $F$ is chi-square. (2) The number in brackets is the standard error of the estimate ${ }^{*} p<0.1 ;{ }^{* *} p<0.05 ;{ }^{* * *} p<0.01$ 
schooling has a significant positive impact on elderly parents' physical mobility; in middle-old and old-old periods, the effect of children's average years of schooling is not significant. For all age groups, an increase in sons' average years of schooling will reduce the probability that they live with their parents; in the middle-old period, an increase in daughters' average years of schooling will increase the probability that they live with their parents (see Table 4).

A better indicator for parents' emphasis on children's education is children's lowest years of schooling. In terms of health conditions, we can see that daughters' lowest years of schooling is significantly positive to elderly parents' self-assessment of health and physical mobility but the effect of sons' lowest years of schooling is not significant. In other words, if the child selected to quit school is a son, then his years of schooling has no significant effect on parents' health condition at old age; however, if it is the daughter, then more years of schooling will benefit her parents' life condition. In terms of economic status, we find that increasing sons' lowest years of schooling can improve parents' economic status and nutrition level, while the daughters' lowest years of schooling is positively related to parents' self-assessment of economic status, but not to parents' meat consumption. By examining living environment, we can see that sons' lowest years of schooling has no significant effect on either housing flooring or cooking energy, while that of the daughters' has a significant positive effect on both flooring and cooking energy, and the significance level is at $1 \%$. That is to say, if daughters leave school, then increasing their years of schooling will have a positive influence on parents' living environment in old age. Sons' lowest years of schooling has a significant negative impact on parents living with their children-the higher sons' lowest years of schooling is, the lower probability for parents' to live with their children-while that of the daughters' has no significant influence (see Table 5).

\section{Optimal child-rearing and its influence on elderly parents' life quality in rural areas}

Considering the trade-off between the quantity and quality of children, there is a strong synchronicity between children quantity, their average years of schooling, and lowest years of schooling. ${ }^{15}$ In the following model, we introduce sons and daughters' highest years of education as the core independent variables since the synchronicity is relatively weak and make respondents' personal, geographical, and period characteristics constant to analyze the influence of optimal child-rearing strategy. The results are shown in Table 6. In general, daughters' highest years of education's positive effect is more significant; compared to sons, an increase in daughters' highest years of education will improve elderly people's life quality.

In terms of health conditions, there is no significant relation between sons' highest years of education and elderly people's self-assessment of health and physical mobility. Thus, if parents choose their optimal child-rearing strategy when they raise their sons, their quality of life will not improve in old age. However, daughters' highest years of education has a positive impact on parents' health assessment and physical mobility, and the significance level is at $1 \%$. By looking at economic status, we find that sons' highest years of schooling has a significant positive effect on elderly people's selfassessed economic status, but not on meat consumption. We can see that sons' highest years of education does not actually improve elderly parents' economic status; parents' 
Table 4 Sons and daughters' average years of schooling's influence on parents' life quality at old age (for different age groups

\begin{tabular}{|c|c|c|c|c|c|c|c|c|c|}
\hline \multirow[t]{3}{*}{ Variables } & \multicolumn{3}{|l|}{$49-59$} & \multicolumn{3}{|l|}{$60-69$} & \multicolumn{3}{|c|}{70 and above } \\
\hline & $\mathrm{R} 1$ & R2 & R3 & $\mathrm{R} 1$ & R2 & R3 & R1 & R2 & R3 \\
\hline & Health & $\begin{array}{l}\text { Relative economic } \\
\text { status }\end{array}$ & $\begin{array}{l}\text { Living with } \\
\text { children }\end{array}$ & Health & $\begin{array}{l}\text { Relative economic } \\
\text { status }\end{array}$ & $\begin{array}{l}\text { Living with } \\
\text { children }\end{array}$ & Health & $\begin{array}{l}\text { Relative economic } \\
\text { status }\end{array}$ & $\begin{array}{l}\text { Living with } \\
\text { children }\end{array}$ \\
\hline Sons' average years of schooling & $-0.06(.014)$ & $.035^{* *}(.017)$ & $-.196^{* * *}(.045)$ & $-.005(.011)$ & $.062^{* *}(.024)$ & $.016(.062)$ & $.039(.043)$ & $.105^{* * *}(.041)$ & $.056(.115)$ \\
\hline $\begin{array}{l}\text { Daughters' average years of } \\
\text { schooling }\end{array}$ & $.030^{* *}(.014)$ & $.080^{* * *}(.018)$ & $-.011(.043)$ & $\begin{array}{l}.031^{* * *} \\
(.011)\end{array}$ & $.064^{* * *}(.022)$ & $.114^{* * *}(.057)$ & $.025(.038)$ & $.040(.036)$ & $-.088(.103)$ \\
\hline \multicolumn{10}{|c|}{ Personal characteristic of the old-aged } \\
\hline Years of schooling & $.017^{* *}(.008)$ & $.021^{* *}(.010)$ & $.042^{*}(.024)$ & $.013^{* *}(.007)$ & $.038^{* * *}(.014)$ & $.015(.036)$ & $.015(.026)$ & $.054^{* *}(.025)$ & $-.037(.071)$ \\
\hline Party membership & $.002(.129)$ & $.361^{* *}(.159)$ & $.360(.382)$ & $.100(.093)$ & $-.096(.185)$ & $-.821(.536)$ & $-.097(.316)$ & $-.141(.302)$ & $-.009(.925)$ \\
\hline Number of siblings & $.005(.018)$ & $-.025(.023)$ & $-.014(.055)$ & $.013(.014)$ & $.015(.027)$ & $.023(.070)$ & $.021(.058)$ & $.009(.055)$ & $.034(.163)$ \\
\hline Geographical characteristic & IN & IN & IN & IN & IN & IN & IN & IN & IN \\
\hline Birth year of children & IN & IN & IN & IN & IN & IN & IN & IN & IN \\
\hline Intercept & $\begin{array}{l}4.248^{* * *} \\
(.216)\end{array}$ & $1.663^{* * *}(.265)$ & $2.323^{* * *}(.666)$ & $\begin{array}{l}4.165^{* * *} \\
(.154)\end{array}$ & $1.375^{* * *}(.332)$ & $-.2441^{* * *}(.879)$ & $\begin{array}{l}2.650^{* * *} \\
(.625)\end{array}$ & $1.829 * * *(.597)$ & $-.254(1.672)$ \\
\hline Valid sample & 490 & 490 & 490 & 490 & 490 & 490 & 490 & 490 & 490 \\
\hline F-value & $2.460^{* * *}$ & $7.451^{* * *}$ & $44.131^{* * *}$ & $13.473^{* * *}$ & $3.683^{* * *}$ & 16.803 & .721 & $2.344^{* * *}$ & 11.673 \\
\hline$R^{2}$ & .049 & .135 & .115 & .131 & .100 & .068 & .064 & .182 & .150 \\
\hline
\end{tabular}


Table 5 Sons and daughters' lowest years of schooling and effects on parents' life quality at old age

\begin{tabular}{|c|c|c|c|c|c|c|c|}
\hline \multirow[t]{3}{*}{ Variables } & \multicolumn{2}{|c|}{ Health condition } & \multicolumn{2}{|c|}{ Economic status } & \multicolumn{2}{|c|}{ Living environment } & \multirow{2}{*}{$\begin{array}{l}\text { Living } \\
\text { pattern } \\
\text { R7 }\end{array}$} \\
\hline & R1 & R2 & R3 & R4 & R5 & R6 & \\
\hline & $\begin{array}{l}\text { Self- } \\
\text { assessment }\end{array}$ & $\begin{array}{l}\text { Physical } \\
\text { mobility }\end{array}$ & $\begin{array}{l}\text { Relative } \\
\text { economic } \\
\text { status }\end{array}$ & $\begin{array}{l}\text { Meat } \\
\text { consumption }\end{array}$ & Flooring & $\begin{array}{l}\text { Cooking } \\
\text { energy }\end{array}$ & $\begin{array}{l}\text { Living } \\
\text { with } \\
\text { children }\end{array}$ \\
\hline $\begin{array}{l}\text { Son's average years } \\
\text { of schooling }\end{array}$ & $.010(.011)$ & $\begin{array}{l}.001 \\
(.011)\end{array}$ & $.045^{* * *}(.013)$ & $.039 * *(.018)$ & $\begin{array}{l}.012 \\
(.012)\end{array}$ & $.041(.030)$ & $\begin{array}{l}-.087^{* * *} \\
(.032)\end{array}$ \\
\hline $\begin{array}{l}\text { Daughter's average } \\
\text { years of schooling }\end{array}$ & $.016^{*}(.010)$ & $\begin{array}{l}.023^{* *} \\
(.10)\end{array}$ & $.058^{* * *}(.012)$ & $.011(.015)$ & $\begin{array}{l}.038^{* * *} \\
(.011)\end{array}$ & $\begin{array}{l}.117^{* * *} \\
(.029)\end{array}$ & $\begin{array}{l}-.009 \\
(.029)\end{array}$ \\
\hline \multicolumn{8}{|c|}{ Personal characteristics of respondents } \\
\hline Years of schooling & $\begin{array}{l}.015^{* *} \\
(.007)\end{array}$ & $\begin{array}{l}.010 \\
(.007)\end{array}$ & $.031^{* * *}(.008)$ & $.014(.010)$ & $\begin{array}{l}.014^{* *} \\
(.007)\end{array}$ & $\begin{array}{l}.068^{* * *} \\
(.018)\end{array}$ & $.021(.019)$ \\
\hline Age & $\begin{array}{l}-.018^{* * *} \\
(.007)\end{array}$ & $\begin{array}{l}-.029^{* * *} \\
(.007)\end{array}$ & $\begin{array}{l}-.019^{* * *} \\
(.008)\end{array}$ & $\begin{array}{l}-.020^{* *} \\
(.010)\end{array}$ & $\begin{array}{l}-.028^{* * *} \\
(.007)\end{array}$ & $\begin{array}{l}-.056^{* * *} \\
(.019)\end{array}$ & $\begin{array}{l}-.101^{* * *} \\
(.020)\end{array}$ \\
\hline Party membership & $.175^{*}(.094)$ & $\begin{array}{l}.158^{*} \\
(.093)\end{array}$ & $.137(.111)$ & $.146(.135)$ & $\begin{array}{l}.046 \\
(.101)\end{array}$ & $.184(.262)$ & $.151(.275)$ \\
\hline Number of siblings & $.000(.014)$ & $\begin{array}{l}.006 \\
(.014)\end{array}$ & $-.007(.016)$ & $.045^{* *}(.022)$ & $\begin{array}{l}-.028^{* *} \\
(.015)\end{array}$ & $\begin{array}{l}-.069^{*} \\
(.038)\end{array}$ & $.007(.040)$ \\
\hline $\begin{array}{l}\text { Geographical } \\
\text { characteristics }\end{array}$ & IN & IN & IN & IN & IN & IN & IN \\
\hline Birth year of children & IN & IN & IN & IN & IN & IN & IN \\
\hline Intercept & $\begin{array}{l}4.084^{* * *} \\
(.419)\end{array}$ & $\begin{array}{l}5.856^{* * *} \\
(.413)\end{array}$ & $\begin{array}{l}2.928^{* * *} \\
(.492)\end{array}$ & $\begin{array}{l}4.595^{* * *} \\
(.650)\end{array}$ & $\begin{array}{l}4.286^{* * *} \\
(.447)\end{array}$ & $\begin{array}{l}2.747 \\
(1.182)\end{array}$ & $\begin{array}{l}6.366 \\
(1.236)\end{array}$ \\
\hline Valid sample & 994 & 994 & 994 & 994 & 994 & 994 & 994 \\
\hline$F$-value & $8.407^{* * *}$ & $14.118^{* * *}$ & $12.526^{* * *}$ & $4.464^{* * *}$ & $10.553^{* * *}$ & $166.063^{* * *}$ & $121.046^{* * *}$ \\
\hline$R^{2}$ & .093 & .147 & .133 & .093 & .114 & .205 & .160 \\
\hline
\end{tabular}

Note: (1) Models R1, R2, R3, R4, and R5 are linear regression models; models R6 and R7 are binomial logistic regression; the output reports for the goodness of fit is Nagelkerke $R^{2}$; and the report for $F$ is chi-square. (2) The number in brackets is the standard error of the estimate. (3) In the segmented regression, the variable used to measure health condition is physical mobility. (4) The model makes geographical characteristics and children's birth year constant and does not include the results in this paper. Interested readers can contact the author for more information ${ }^{*} p<0.1 ;{ }^{* *} p<0.05 ;{ }^{* * *} p<0.01$

tend to feel that their economic status rises with their sons' social and economic status, which is largely the result of traditional culture, which advocates "to be respected for sons' achievement" and "to live with sons." Daughters' highest years of schooling has a significant positive effect not only on elderly parents' relative economic status but also on their meat consumption. Therefore, if parents' choose daughters as the object of optimal child-rearing, then it can indeed improve parents' economic status. When examining the living environment, we find that daughters' and sons' highest years of schooling affect elderly parents' life quality differently. Regression shows that sons' highest years of schooling has no significant effect on cooking energy and only has a significant and positive effect on parents' flooring at a $10 \%$ significance level. Daughters' highest years of schooling has a significant effect on both parents' flooring and cooking energy, at $1 \%$ significance level, and its standardized regression coefficient is 2.03 times greater than that of sons'. If we look at the living pattern, we can see that there is a positive relationship between daughters' highest years of schooling and parents' living with children, although it is not significant, while there is a significant negative relationship between sons' highest years of schooling and parents' living with children $(p=0.001)$. The more education 
Table 6 Sons and daughters' highest years of schooling and the influence on elderly people's life quality in rural areas

\begin{tabular}{|c|c|c|c|c|c|c|c|}
\hline \multirow[t]{3}{*}{ Variables } & \multicolumn{2}{|c|}{ Health conditions } & \multicolumn{2}{|c|}{ Economic status } & \multicolumn{2}{|c|}{ Living environment } & \multirow{2}{*}{$\begin{array}{l}\text { Living } \\
\text { pattern } \\
\text { R7 }\end{array}$} \\
\hline & R1 & R2 & R3 & R4 & R5 & R6 & \\
\hline & $\begin{array}{l}\text { Self- } \\
\text { assessment }\end{array}$ & $\begin{array}{l}\text { Physical } \\
\text { mobility }\end{array}$ & $\begin{array}{l}\text { Relative } \\
\text { economic } \\
\text { status }\end{array}$ & $\begin{array}{l}\text { Meat } \\
\text { consumption }\end{array}$ & Flooring & $\begin{array}{l}\text { Cooking } \\
\text { energy }\end{array}$ & $\begin{array}{l}\text { Living } \\
\text { with } \\
\text { children }\end{array}$ \\
\hline $\begin{array}{l}\text { Sons' average years } \\
\text { of schooling }\end{array}$ & $.003(.009)$ & $\begin{array}{l}-.003 \\
(.404)\end{array}$ & $.043^{* * *}(.011)$ & $.010(.015)$ & $\begin{array}{l}.018^{*} \\
(.010)\end{array}$ & $.014(.025)$ & $\begin{array}{l}-.077^{* * *} \\
(.028)\end{array}$ \\
\hline $\begin{array}{l}\text { Daughters' average } \\
\text { years of schooling }\end{array}$ & $\begin{array}{l}.023^{* * *} \\
(.010)\end{array}$ & $\begin{array}{l}.026^{* * *} \\
(.010)\end{array}$ & $.051^{* * *}(.011)$ & $.027^{*}(.015)$ & $\begin{array}{l}.038^{* * *} \\
(.010)\end{array}$ & $\begin{array}{l}.100^{* * *} \\
(.027)\end{array}$ & $.019(.028)$ \\
\hline \multicolumn{8}{|c|}{ Personal characteristics of respondents } \\
\hline Years of schooling & $\begin{array}{l}.014^{* *} \\
(.007)\end{array}$ & $\begin{array}{l}.010 \\
(.007)\end{array}$ & $.032^{* * *}(.008)$ & $.015(.010)$ & $\begin{array}{l}.014^{* *} \\
(.007)\end{array}$ & $\begin{array}{l}.072^{* * *} \\
(.018)\end{array}$ & $.017(.019)$ \\
\hline Age & $\begin{array}{l}-.018^{* * *} \\
(.007)\end{array}$ & $\begin{array}{l}-.029^{* * *} \\
(.007)\end{array}$ & $\begin{array}{l}-.023^{* * *} \\
(.004)\end{array}$ & $\begin{array}{l}-.023^{* * *} \\
(.010)\end{array}$ & $\begin{array}{l}-.030^{* * *} \\
(.007)\end{array}$ & $\begin{array}{l}-.061^{* * *} \\
(.019)\end{array}$ & $\begin{array}{l}-.096^{* * *} \\
(.020)\end{array}$ \\
\hline Party membership & $.170^{*}(.094)$ & $\begin{array}{l}.149 \\
(.093)\end{array}$ & $.139(.111)$ & $.135(.136)$ & $\begin{array}{l}.037 \\
(.101)\end{array}$ & $.181(.261)$ & $.096(.275)$ \\
\hline Number of siblings & $.000(.014)$ & $\begin{array}{l}.007 \\
(.014)\end{array}$ & $-.005(.016)$ & $.047^{* *}(.022)$ & $\begin{array}{l}-.028^{*} \\
(.015)\end{array}$ & $\begin{array}{l}-.062^{*} \\
(.038)\end{array}$ & $.005(.040)$ \\
\hline $\begin{array}{l}\text { Geographical } \\
\text { characteristics }\end{array}$ & IN & IN & IN & IN & IN & IN & IN \\
\hline Birth year of children & IN & IN & IN & IN & IN & IN & IN \\
\hline Intercept & $\begin{array}{l}4.107^{* * *} \\
(.410)\end{array}$ & $\begin{array}{l}5.872^{* * *} \\
(.404)\end{array}$ & $\begin{array}{l}3.203^{* * *} \\
(.484)\end{array}$ & $\begin{array}{l}4.815^{* * *} \\
(.633)\end{array}$ & $\begin{array}{l}4.325^{* * *} \\
(.438)\end{array}$ & $\begin{array}{l}3.398^{* * *} \\
(1.154)\end{array}$ & $\begin{array}{l}5.788^{* * *} \\
(1.207)\end{array}$ \\
\hline Valid sample & 994 & 994 & 994 & 994 & 994 & 994 & 994 \\
\hline$F$-value & $8.581^{* * *}$ & $14.302^{* * *}$ & $12.005^{* * *}$ & $4.274^{* * *}$ & $10.846^{* * *}$ & $157.475^{* * *}$ & $119.582^{* * *}$ \\
\hline$R^{2}$ & .084 & .138 & .128 & .068 & .106 & .195 & .159 \\
\hline
\end{tabular}

Note: (1) Models R1, R2, R3, R4, and R5 are linear regression models; models R6 and R7 are binomial logistic regression; the output reports for the goodness of fit is Nagelkerke $R^{2}$; and the report for $F$ is chi-square. (2) The number in brackets is the standard error of the estimate. (3) In the segmented regression, the variable that is used to measure health conditions is physical mobility. (4) The model makes the geographical characteristics and children's birth year constant and does not include the results in this paper. Interested readers can contact the author for more information ${ }^{*} p<0.1 ;{ }^{* *} p<0.05 ;{ }^{* * *} p<0.01$

sons receive, the more likely they will work and live in urban areas, and this reduces the probability that they will live with their parents; for daughters, on the other hand, receiving more years of education will increase the possibility of living with parents.

Compared to average years of schooling and lowest years of schooling, the highest years of schooling has a more stable effect on parents' life quality at old age because there are more variables that are significant and at a more significant level. If we construct a comparison within the significant variables, we can see that the standardized partial coefficient is relatively larger. As an example, this is true for the regression of self-assessed health condition, and the partial regression coefficient on the highest years of schooling is 0.077 , on the lowest years of schooling is 0.055 , and on the average years of schooling is 0.068 .

Children's highest years of schooling has a different effect on life equality during different periods of old age. In early old (49-59 years) and middle old (6069 years), the more years daughters stay at school, the better parents' health and economic conditions, and the more care daughters provide for parents; but in the 
old-old (70 and above) period, sons' highest years of schooling has a more significant effect with a significance level of $1 \%$. In general, children's average and lowest years of schooling have a similar influence on life quality during different periods of old age.

\section{Conclusion and implication}

"More children bring more blessings" has been regarded as an obstacle in implementing a child planning policy, as well as the reason for the vicious circle of high fertility and increased poverty, but there is unanimous consensus among scholars that giving birth to more children and preferring to have sons is a reasonable rationale, given living in a resource-limited environment. Since economic reform and expansion in China, people's living standards have improved and the child planning policy has been effectively implemented, causing a diversified fertility strategy: people can choose to give birth to more children, to give birth to fewer children but to invest more in their children's education, or to give birth to more children but invest more in one particular child. This paper examines the impact that these three different fertility strategies have on parents' life quality during old age, particularly focusing on gender differences in who provides care, and when, for elderly parents. This results suggest that parents' centralization of resources and optimal child-rearing of particular children has a greater impact on improving parents' life quality during old age, providing education for all children has a smaller impact, and solely giving birth to more children, without providing for their education, only has negative effect on parents' life quality. This means that more children do not bring more blessings. There is a trade-off between the quantity and quality of children in providing family care for elderly parents: the quality of children, as measured by education, has a greater positive impact on parents' life quality at old age, but too many children will decrease parents' benefits.

Compared to increasing children's average years of schooling, increasing children's highest years of schooling has a more significant and positive effect. In the 1970s and 1980s, resource limitations contributed to rural residents' fertility strategies and children's education levels. Because there were only limited resources, rural families could only focus on particular children to secure their quality life at old age. In addition, peasants have no idea how to bring up their children, and they in general do not interfere with children's education. When parents have more children, they believe they increase the likelihood they will raise outstanding children; therefore, giving birth to more children and investing in particular ones is their optimal choice. Because of the child planning policy, there are fewer fertility strategies for the birth-planned families. It is true that there are fewer resource limitations for these families but the opportunities for children's development also decrease; they lose the possibility of investing in the quantity of children and yet do not receive more opportunities to invest in children's quality (Li 2004). From the perspective of family development, having the government give extra points to the only child of the family and in some geographic areas is, to some extent, reasonable.

Compared with sons', increasing daughters' years of schooling is more efficient in improving rural parents' life quality during old age. But the effects during different periods of old age vary significantly. In early-old and middle-old stages, the greater the number of years of education for daughters, the better parents' health and economic conditions, 
and further, daughters provide more care for them; while in the old-old period, in contrast, sons' years of education has a more significant positive impact on elderly parents' life quality but only in terms of economic aspects. No matter whether it is the children's average years of schooling or their highest years of schooling, the positive relation exists, suggesting that the effect of education is very stable.

In terms of living pattern, sons' years of schooling and parents living with sons are negatively related. If parents choose to invest in sons, they have less likelihood of living with them because sons are more likely to move to urban areas and start their own families there; in contrast, if parents choose to invest in daughters, parents still have the possibility of living with their daughters if they receive relatively high levels of education. This may be explained by Fei's (1983) theory that the patrilineal relation in urban areas and the tradition of living with the father is dissolving, resulting in daughters living with parents after they get married. Thus, the matrilineal family relationship is expanding.

This research shows that, in contemporary rural China, more children do not necessarily bring more blessings; on the contrary, greater investment in children's education benefits elderly parents' life quality at old age, and daughters' years of schooling, in particular, has a significant positive impact on parents' life quality during old age. This result should influence and change people's fertility preferences, gradually diminishing the idea of "more children bring more blessings" and the preference for sons, and therefore, the current adjustment in the birth planning policy-which allows couples where both spouses come from one-child families to have a second child-will not result in a sharp bounce in the fertility rate but will benefit the sustainable development of rural areas; however, relaxing the child planning policy to allow all families to have two children will be even more beneficial. Some remote areas have limited resources to provide family care and limited capital to invest in children's education; they choose to give birth to more children in order to secure their quality of life during old age. In order to solve this problem, on the one hand, the government should invest more in public education, especially in compulsory education, to provide more financial support for the construction of schools and hiring teachers and to change the current situation in rural areas. On the other hand, the social security system in rural areas should be further improved to make the parents less economically dependent on their children. Social support should be provided for parents who have only one child, particularly those who have lost their only child, and to release them from the anxiety and stress from the risk of losing their one child.

\section{Endnotes}

${ }^{1}$ Among the rural families that are investigated, $61.5 \%$ who had children who were born before December 1984 and were unplanned birth were not punished or were punished but were not charged with a social upbringing fee-and even if they were charged, the amount was very little. Interviews with local family planning offices showed that the State formally encouraged to have one child in 1980 and birth planning was written into the Constitution in 1982. But before 1984, there had not been an efficient population census and an evaluation system for birth planning; for example, it was not until March 1988 that the "Family Planning Regulation for Hubei Province" was officially implemented. Because people had limited knowledge of the family 
planning law, during this period, there was a strict policy but a relaxed implementation at the local level. For the family planning offices at the grassroot level, the fewer reports of unplanned births, the better. However, even though the policy was only partially implemented, it still caused conflicting situations. Therefore, after 1984, many areas started the "one child and a half" policy. Later, there seemed to be a relaxation in birth planning policy, but in fact, it was a perfection of the current one and with better implementation.

${ }^{2}$ (Translation note) "San ti" refers to the money collected by the village collective economic organizations from the peasants for the purpose of maintaining and expanding production, setting up charity business, and everyday administration, which included provident fund, public charity fund, and administration fee. "Wu tong" refers to the money collected by the township collaborative economic organizations. The money is spent on education at the village and township level, family planning, special care for soldiers and their family, trainings for militia, and road constructions.

${ }^{3}$ There are limited opportunities for rural students to be enrolled in high schools, and the opportunities are decreasing over the years. However, the enrollment rate for urban students is increasing, which resulted in a bigger discrepancy between the enrollment rate of rural students and that of the urban students. The discrepancy increased from $37.8 \%$ in 1987 to $59.7 \%$ in 2010 .

${ }^{4}$ The main difference between the highest years of education and the lowest years of education is that parents can decide which child should drop out of school; they cannot decide if their children can complete the full 9 years of compulsory education or whether children can attend either high school or university.

${ }^{5}$ Nuclear family is a family unit that includes two married parents of opposite genders and their biological or adopted children living in the same residence.

${ }^{6}$ Generally speaking, once the daughter gets married and has a family of her own, then she has less time and fewer resources to care for her parents in rural China.

${ }^{7}$ The reason for choosing families with wives over 49 was to ensure we could make a valid comparison. Females had normally passed childbearing age. In these families, fertility strategies have been made and fertility behavior realized.

${ }^{8}$ According to the "one and a half" child policy in rural areas, families with a daughter and a younger son are "birth-planned" families, while those with a son and a younger daughter are "non-planned" families.

${ }^{9}$ Because of the word limits, the model variables are not introduced and statistical tables are not listed. Interested readers can contact the author for more information.

${ }^{10}$ Physical mobility is objective, and the options include (1) normal activities, (2) cannot do heavy agricultural work but can do light work, (3) cannot do any agricultural work but can do some light housework, (4) cannot do housework but can take care of oneself, and (5) cannot take care of oneself. When modeling, the values that refer to sequence number are reversed that from 1 to 5 , a higher value means better health condition.

${ }^{11}$ In econometrics, measurement error is a common problem and also is difficult to deal with. Following Brown and Tierney (2009), we believe that the likelihood of systematic bias is slim.

${ }^{12}$ In the 1950s, China adopted the "people's commune system" in its rural areas in a socialist campaign. Farmers were organized into small production teams, and teams into brigades, and brigades into communes. Members of each production 
team, the basic work unit, would start and finish each day's work together just like workers in a factory. Farmers above the age of 18 earned 10 work points each day, and those under 18 got 8 to 9 points. Each individual farmer would get his payment, which was based on annual accumulation of his daily work points, usually at the end of each year, both in kind and in cash.

${ }^{13}$ Because of word limits, we only report the unstandardized coefficients of this multiple linear regression model. If there are no further explanations, then the unstandardized coefficients are consistent with the standard partial regression coefficient.

${ }^{14}$ Considering that the percentage of one-son family and one-daughter family is relatively low, we used listwise deletion to deal with variables with missing values. That is to say, if the family has only son(s) which means that the highest years of education of daughters is a missing value, then the case is deleted from the model. So are families with only daughter(s). Therefore, all families included in the regression model are families with both sons and daughters.

${ }^{15}$ The regression results between the quantity of children and children's lowest, highest, and average years of schooling can be found in previous discussions.

Competing interests

This study was supported by the National Social Science Major Research Program Foundation, 2011.

Received: 6 April 2016 Accepted: 2 June 2016

Published online: 26 July 2016

References

Angrist, J.D., and W.N. Evans. 1998. Children and their parents' labor supply: Evidence from exogenous variation in family size. American Economic Review 88(3): 450-477.

Arnold. 1991. Measurement of quality of life in the frail elderly. In The concept and measurement of quality of life in the frail elderly, ed. J.E. Birren, J.E. Lubben, Rowe Janice Cichowlas, and Donna E. Deutchman, 50-73. San Diego: Academic Press.

Becker, G.S. 1960. An economic analysis of fertility. In Universities-National Bureau. Demographic and economic change in developed countries. New York: Columbia University Press.

Becker, G.S. 1974. A theory of social interactions. Journal of Political Economy 82: 1153-1189.

Becker, G.S. 1992. Fertility and the economy. Journal of Population Economics 5: 185-201.

Blake, J. 1981. Family size and the quality of children. Demography 18(4): 421-442.

Brown, P., and B. Tierney. 2009. Religion and subjective well-being among the elderly in China. Journal of SocioEconomics 38(2): 310-319.

Chen, Jieming. 1998. Investment and care: A causal analysis of generational exchange in cities. Social Sciences in China 6: 131-149.

Chen, Wei, and Xia Du. 2002. Factors influencing care provision and life quality of Chinese elderly people-A test of children quantity and sex. Chinese Journal of Population Science 6: 123-128.

Chiswiek, B. 1978. The effects of Americanization on the earnings of foreign-born men. Journal of Political Economic 86 897-921.

Chu, C.Y., Cyrus, Y. Xie, and R.R. Yu. 2007. Effects of sibship structure revisited: Evidence from interfamily resource transfer in Taiwan. Sociology of Education 80(2): 91-113.

Downey, D.B. 1995. When bigger is not better: Family size, parental resources and children's educational performance. American Sociological Review 60: 746-761.

Fei, Xiaotong. 1983. Issues of family support for elderly people in the changes of family structure-Another argument about changes of Chinese family structure. Journal of Peking University (Philosophy and Social Science Edition) 3: 7-16.

Fei, Xiaotong. 1985. Earthbound China. Beijing: Sanlian Bookshop.

Geng, Dewei. 2013. More children bring more blessing? Quantity of children and its influence on parents' health. South China Population 28(3): 8-16.

Guo, Zhigang. 2002. Living pattern of Chinese elderly people and related factors. Population Research 1: $37-42$.

Guo, Zhigang. 2011. 2010 population census data indicates serious miscount in past population estimation and projection. Chinese Journal of Population Science 6: 2-13.

Guo, Zhigang, and Kaidi Zhang. 1996. Retesting the role of the number of children in family support for the elderly. Population Research 20(2): 7-15.

Gonzalez, E. T. 1991. Health, education and family planning in the Philippines: Governmental initiatives and household choice. Paper presented at the Annual Meeting of the Population Association of America, Washington, D. C. (January 1):1-31.

Goode, W.J. 1963. World revolution and family patterns. Glencoe: Free Press.

Hanushek, E.A. 1992. The trade-off between child quantity and quality. Journal of Political Economy 100: 84-117. 
Hannum, E. 2003. Poverty and basic education in rural China: Villages, households and girls' and boys' enrollment. Comparative Education Review 47(2): 141-159.

Hua, Y.F. 2009. The development and prospects of China's old-age security system. Social Sciences in China 30(1): 185-196.

Li, Jianmin. 2004. Elderly care for birth-planned couple's in rural areas and a study of social security system. Chinese Journal of Population Science 3: 40-48.

Li, Yinhe. 1994. Fertility and village culture. Beijing: The China Social Sciences Press.

Lin, N., L. Wang, Y. Pan, and G. Yuan. 1987. The structure and indicators of life quality. Sociological Studies 6: 73-89.

Liu, Jing. 2004. The impact of number of children on the support for elderly people in rural areas and their life quality. Chinese Journal of Population Science 7: 48-54.

Liu, Zilan. 2003. Reflection and reconstruction of Chinese social security system and the care provision for elderly people. Management World 8: 46-56.

Lu, S., and L. Wei. 1992. A study of objective and subjective indicators for life quality. Social Sciences in China 1:121-136.

Lundberg, S., and E. Rose. 2002. The effects of sons and daughters on men's labor supply and wages. Review of Economics and Statistics 84(2): 251-268.

Martina, A. 1996. The quantity/quality of children hypothesis in developing countries: Testing by considering some demographic experiences in China, India and Africa. Health Transition Review 6: 191-212.

Millimet, D.L., and L. Wang. 2011. Is the quantity-quality trade-off a trade-off for all, none, or some? Economic Development and Cultural Change 60(1): 155-195.

Mutharayappa, R. 1997. Is son preference slowing down India's transition to low fertility. National Family Health Survey Bulletin 4: 1-4.

Pei, X.M., and V.K. Pillai. 1999. Old age support in China: The role of the state and the family. The International Journal of Aging and Human Development 49(3): 197-212.

Qiao, B., J. Fan, and X. Feng. 2005. Fiscal decentralization and compulsory primary education in China. Social Sciences in China 27(2): $62-76$.

Shi, Zhilei. 2014. How birth planning influence family development and its policy meaning. Public Journal of Management 4: 83-94.

Shi, Z., and Y. Yang. 2012. Family endowment, family decision and returning of rural migrants. Sociological Studies 3 : 157-180.

Steelman, LalaCarr. 2002. Reconsidering the effects of sibling configuration: Recent advances and challenges. Annual Review of Sociology 28: 243-269.

Watson, J.A., and V.R. Kivett. 1976. Influences on the life satisfaction of older fathers. The Family Coordinator 25(4): 482-488.

Wu, Cangping. 2002. Improve the scientific understanding of life quality for elderly people. Population Research 5: 1-5.

Xia, C., and F. Ma. 1995. Quantity of children's impact on family support for elderly people. Population Research 1: 10-16.

Yang, H.Q. 1996. The distributive norm of monetary support to older parents: A look at a township in China. Journal of Marriage and the Family 58: 404-415.

Yang, J., and L. Li. 2009. Intergenerational interaction and family coherence: A comparative study of East Asian countries and regions. Sociological Studies 3: 26-53.

Ye, Y., Y. Zhong, Y. Wu, J. Huang, L. Xiao, L. Zhao, J. Chang, N. Li, and J. Huang. 2007. The correlation between elderly people's life quality and their living conditions in rural China. Chinese Journal of Gerontology 1: 49-51.

Yuan, Zhigang. 2001. An economic analysis of Chinese choice of social security system for providing care for elderly people. Economic Research Journal 5: 13-19.

Zeng, Tianshan. 1998. Experiences and strategies from the development of education in poor areas of China. Nanning: Guangxi Education Publishing House.

Zhou, L., G. Chen, and Z. Wang. 2012. Impact of children's gender and birth order on intergenerational economic transfer in rural China. Population Journal 1: 22-30

Zhu, C., and Q. Xu. 1992. Family care of the elderly in China. In Family care of the elderly: Social and cultural changes. In Newbury Park, ed. J.l. Kosberg. CA: Sage.

Zhu, Qin. 2012. Estimation on fertility level in China 2000-2010: Preliminary study based on the 2010 Population Census. Chinese Journal of Population Science 4: 68-77.

\section{Submit your manuscript to a SpringerOpen ${ }^{\circ}$ journal and benefit from:}

- Convenient online submission

Rigorous peer review

- Immediate publication on acceptance

- Open access: articles freely available online

- High visibility within the field

- Retaining the copyright to your article

Submit your next manuscript at $\boldsymbol{\sim}$ springeropen.com 